\title{
Effects of Bank Credits on the Manufacturing Sector Output in Nigeria (1981-2018)
}

\author{
Okere Peter.A Phd ${ }^{1}$, Okere,Cletus $\mathrm{O}^{2}$, Nwaneto Ugonma ${ }^{3}$ \\ ${ }^{I}$ Dept. of Banking and Finance Imo State Polytechnic, Umuagwo-Ohaji \\ ${ }^{2}$ Dept. of Accountancy, Imo State Polytechnic, Umuagwo-Ohaji \\ ${ }^{3}$ Dept of Business Admin \& mgt, Federal polytechnic, Nekede, Imo stae
}

\begin{abstract}
This study investigated the effects of bank credits on the manufacturing sector output in Nigeria from 1981 2018. The data for this study were sourced from Central Bank of Nigeria (CBN) statistical bulletin. The study adopted the Auto-Regressive Distributed Lag (ARDL) bound cointegration test approach and error correction. In the bound test following the ARDL, it investigated that the variables of interest put in the model are bound together in the long-run and error correction term displayed a negative and statistically significant. The negative value shows that there exists an modification speed from short-run disequilibrium towards the long-run balance. Given the error correction instrument outcome, the study revealed that bank credits exhibited a optimistic and significant relationship with the presentation of manufacturing sector in Nigeria. The study therefore recommends that policies geared towards deepening the financial sector and enhancing the healthy and soundness of banks should be vigorously pursued. Also the Central Bank of Nigeria should as a matter of urgency review downwards the lending interest rate in view of this COVID-19 pandemic threatening the whole world.
\end{abstract}

Keywords: Bank Credits, Financial Deepening, Interest Rate and Manufacturing Sector Output.

\subsection{Introduction}

The doctrines of financial disequilibrium and intermediation imply the financial concepts of lending and borrowing. What finance does to resolve the disequilibrium and ensure intermediation is to bring the deficit units and the surplus units together within an institutional framework and mechanism to consummate the needed financial transaction (Ezirim, 2005). Deposit money banks play a most indispensable role when they pool together funds from the surplus economic units and rechannel these resources to the deficit economic units.

By this, bank credits play a significant and fundamental role in boosting the manufacturing sector performance through purchasing machinery required to boost production. Manufacturing as a procedure involve change of raw resources into finished consumer goods or intermediates/semi-finished goods. Like other industrialized activities, manufacturing creates employment, boost farming and diversifies the economy while helping the nation to increase its foreign replace earnings. Additionally, it enables local labour to acquire skills (Ume, Obasikene, Oleka, Nwadike and Okoyeuzu,2017).

The financial institutions in Nigeria are highly liquid to make industrial loans, but they believe that lending to the manufacturing sector is not justified in terms of risks and costs (Olorunsola, 2001). The impact of the credit been extended to manufacturing so far has not been felt though high lending rate which is sometimes go beyond thirty percent makes such credits unattractive, given the information to income on investments in the sub-sector have been below ten percent $(10 \%)$ on the standard. This perceived high risk ranges from difficulty in obtaining information on a firm's true financial condition and performance, inadequacies in the legal environment including long delay in adjudicating cases of debtor delinquency and problems with contract enforcement and unfriendly economic environment. Consequently, banks charge high interest rate, demand high level of security and make few loans less than the loan requests.

In Nigeria like most growing countries, poor access to manufacture funds has been blamed for the nearabsence of growth of the developed sector (Adelegan, 2011). He opined that managers of firms complain that 
inadequate finance and high interest rates are major constraints to doing business in Nigeria. In Zimbabwe too, the role of banks in the development of the manufacturing sector has not been completely addressed and the impact has not been completely felt. Manufacturing sector has been experiencing a stunted growth and its contribution to gross domestic product has remained low whilst bank credits and advances were increasing and being allocated yearly to the manufacturing sector in Nigeria. The unimpressive performance of the manufacturing sector in Nigeria has also been characterised to massive importation of semi- finished and finished goods from countries and inadequate financial support for the manufacturing sector, which ultimately has contributed to the reduction in capacity utilization of the manufacturing sector in Nigeria and many other African countries.

A glance at manufacturing sector output as at 2016 shows that value added of the manufacturing sector decline to \#6586.62 billion and declined further to \# 6288.9 billion in 2017, and in 2018, a snail movement increase was noticed as it stood at \# 6420.54 billion. It is expected the decline will continue more especially in the COVID -19 pandemic, where the whole businesses have been on shutdown. Manufacturing sector plays a vital role in a modern economy and has many dynamic benefits crucial for economic transformation and development. The continuous policy strategies by the monetary authorities to attract credits to the real sector theviz-a vis the manufacturing sector has been encouraging. The Nigerian manufacturing enterprises have received the highest funding in the real sector from 1981 to 2006. From the CBN statistical bulletin, it could be observed that credits to the manufacturing sector started losing preference of the banks from 2007. In 2007 banks started paying more attention to mining and quarying, and real estate and construction. But despite all the credits to the manufacturing sector, the impact has not been felt. Manufacturing sector in Nigeria has been experiencing a stunted growth and its contribution to gross domestic product (GDP) has remained low. For instance, the manufacturing as a whole remains small, accounting for only 9.1 percent of GDP in 218 and 9 percent of employment (World Bank, 2018).

However, many manufacturing firms in the Nigeria have continued to rely heavily on internally generated funds (may be because of the high interest rate and security requirement) which tends to limit their scope of operation. Additionally and most importantly, the manufacturing sector requires much credits than the banks are making available sectorially.

Therefore, the broad objective of this study is to evaluate the effect of deposit money banks' credit on the manufacturing sector development in Nigeria from 1981- 2018. The specific objectives are to;

1. investigate the effect of deposit money bank credits on manufacturing sector, development,

2. establish the relationship between interest rate and manufacturing sector development,

3. evaluate the effect of broad money supply on manufacturing sector development,

4. Establish the relationship between inflation and manufacturing sector development.

\subsection{Review of Related Literature \\ 2.1 Conceptual Review}

There are three ways of measuring the performance of manufacturing sector. These include manufacturing production output, employment in the manufacturing sector, capacity value-added. However, in this paper, emphasis would be based on the first measure which is manufacturing production output. The financial intermediation of banks entails channeling of funds so mobilized from the surplus economic units to the deficit economic units. This process involves a careful transmission mechanism whereby these funds transferred seamlessly and repayment done as when due. The efficiency of the process depends on also on the financial deepening of the system.

The level of financial deepening reflects the soundness of the financial sectorand the ability with which credits are created with respect to lending and deposit rates. Economic deepen theory thus defines the positive role of the economic system on financial growth by the size of the sector's activity. That means that an economy with more intermediary activity is assumed to be doing more to generate efficient allocations. In development studies, financial deepening is very often refers to the increased provision of financial services with a wider choice of services geared to the development of all levels of society. The size of the financial sector is usually measured by two basic quantitative indicators: "monetization ratio" and "intermediation ratio". Where monetization relation include money-based pointer or fluid legal responsibility like broad money supply to GDP 
ratio, intermediation ratio consists of indicators about to bank-based events like bank credit to the confidential sector and capital market-based events such as capitalization ratio of stock market(Ndebbio, 2004).

The benchmark policy rate set by the monetary authority directly affects interest rates that banks and other financial institutions charge. These charges by banks for on lending to economic agents are, however, determined by both explicit and implicit costs. The explicit costs are the costs of obtaining deposits, while the implicit cost is the opportunity cost associated with firms' use of its own resources. In Nigeria, there is growing disaffection among investors and entrepreneurs on the current high cost of production, which has constrained their efforts at creating wealth and reducing unemployment in the country (Okafor, 2016). Globally, Nigeria ranks 52nd and 170th on both the ease of getting credit and doing business, respectively, out of 189 economies examined by the World Bank in its Ease of Doing Business publication (2015).

Despite these interventions, interest rates charged by banks have remained high making credit expensive for the private sector, particularly those engaged in capital-intensive production processes. This has led to the folding up of manufacturing firms contributing to job losses and declining output.

\subsection{Theoretical Framework}

\subsubsection{Endogenous growth theory:}

The development of endogenous growth theory gave a bigger scope of banking sector and economic growth, it suggest that a strong banking sector promotes economic growth and holds that policy measures can have an impact on the long run growth rate of an economy. Within these models, Romer $(1986,1990)$ enhanced the definition of investment to contain human capital and allow for externalities in investment. Given that he suggested that return on investment are slightly diminishing or even non-diminishing. Following this idea, it is financial institutions, when properly fulfilling their tasks that can generate externalities in investment and by these secure non-diminishing returns to investment in the endogenous growth model. The main implication of this theory therefore, is that banking policies which embraces openness, competition, change and innovation will promote economic growth.

\subsubsection{Financial Intermediation Theory}

Financial institution loans plays serious role in fiscal intermediation which channel resources to units in the economy that make use of them for productive usage. The conceptual framework that initiates the relations between productive sector, fiscal intermediation and growth is enclosed in the research of Goldsmith (1969), Schumpeter (1934) \& Shaw (1973). Of which they showed the important roles financial mediation displays or executes in boosting economic growth and rapid development. Bencivenga and Smith (1991) stated that the banking industry advancement in boosting financial mediation plays a pivotal role in the development of a nation by moving savings to serious productivity

\subsubsection{Solow-Swan Growth Model}

Solow \& Swan (1956) present what later was seen as growth model for economics during the 1950s. This concept opined that there are decreasing returns to capital and labour. Capital from savings is gathered as output of workers decreases because of population increase and depreciation. The decreasing returns in capitalist economy may get to a situation where progress in technology and worker per capital will be constant and growth will discontinue. This stage is known as steady state.

The proponent of the framework says that nations can conquer this level and continue to experience growth by making use of modern/new technology. Even on the long-run output of capital will rely on the savings level though output growth does not rely on savings level. The situation by which nations continue to experience growth despite the decreasing returns is exogenous which leads to new technology creation that allows production with resources that are available, and makes a nation to grow. The intriguing prediction of the concept is that developing nations can grow quicker and catch-up with developed nations if the nations operation on almost the same savings and technology level.

\subsection{Empirical Review}

Fundamentally, several experiential literature abound on the study of bank Credit and the developed sector. These literatures differ in terms of time, space, setting and method 
Muchingami, Monamets and Paradza(2017) examined the impact of bank lending on manufacturing sector performance in Zimbabwe 2009-2015 using ordinary least squares (OLS) regression model. The study established a positive relationship between commercial bank loans and volume of manufacturing index. But the work of Adolphus and Deborah (2014) on the role of banks in financing the agriculture and manufacturing sectors in Nigeria from 1981 to 2010 which employed employed descriptive statistics combined with multiple regression analysis revealed that there exists a significantly weak correlation between commercial bank lending and the contribution of agriculture to GDP and a significantly positive correlation between mercantile bank lending and undeveloped payment to GDP.

Ume, Obasikene, Oleka, NwadikeandOkoyeuzu(2017)examined the relative impact of Bank credit on the manufacturing sector in Nigeria' 1986-2013. The study adopt the autoregressive dispersed lag (ARDL) bound addition test approach and error correction demonstration and found out that there is significant between bank credit and developed sector in Nigeria. This result is corroborate by the Dynamic ordinary least square results as well as the long run estimate of the ARDL. This study collaborated with the study of Ogar, Nkamere, and Effiong,(2014) who examined how commercial bank credit can influence manufacturing sector in Nigeria using a time series data for a sample period of 1992-2011. The study utilizes normal least squares manifold regression analysis and exposed that commercial bank credit had a important association on developed sector in Nigeria.

Ogunsakin, (2014) conducted an empirical investigation of the impact of financial sector reforms on the performance of manufacturing sector in Nigeria from 1980 to 2009 . The study employed the multivariate cointegration method by Johansen. Findings from the study showed that financial sector reforms in Nigeria did not have significant impact on the growth of manufacturing out-put in Nigeria during study period.

Andabai and Eze, (2018) examined a causality investigation of bank credit and manufacturing sector growth in Nigeria for the period of 1990-2016. Secondary data were used and sourced from Central Bank of Nigeria Statistical Bulletin. Vector Error Correction Model was used and it revealed that bank credit had no short-run equilibrium significant relationship with manufacturing sector growth in Nigeria. Causality test indicated that bank credit had no causal relationship with manufacturing sector growth in Nigeria. The study concluded that bank credit had not significantly contributed to manufacturing sector growth in Nigeria.

Olanrewaju, Aremoand Aiyegbusi (2015) empirically study the effect of banking sector reforms on the output of developed sector in the Nigerian financial system between 1970 and 2011 with a view to investigative the extent of the impact of banking sector reforms on the developed sector. The study utilized yearly time series data from 1970 to 2011; adopt the addition analysis and error correction mechanism (ECM). The result revealed that Bank assets, lend rate, Exchange rate (EXR) and genuine attention rate have low and absolutely significant effect on developed output while financial deepening and interest rate have negative and significant crash on the output growth of developed sector in Nigeria.

Olokoyo, Adetioye and Ikpefan (2016) investigated the effects of bank's intermediation role on industrial output in developing economies from 1981 to 2011. Error correction model test was employed and finding revealed and inelastic relationship between bank credits and industrial output in the long-run.

Mesagan, Olunkwa and Yusuf (2018) focused on financial sector development and manufacturing performance in Nigeria over the period of 1981 to 2015. Error Correction Model was used and the study observed that credit to the private sector and money supply positively but insignificantly enhanced capacity utilization and output, but negatively impacted value added of the manufacturing sector in the short run. Present is slight development in the long where both currency supply and credit to confidential sector exert positive crash artificial output.

Sogules and Nkoro (2016) studied the impact of bank credits on performance of manufacturing sector using annual time series data from 1970-2013. Use co-integration and error alteration instrument for the investigation the study exposed that a long run association exists between bank credits and developed sector output. Given the error correction instrument outcome, the study exposed that bank credits exhibited negative significant crash on the presentation of developed sector in Nigeria. Linked in giving out these credits to the developed Sector and also its adverse effect on developed output when misappropriate. 
Otubu (2019) examined the impact of bank credits on the manufacturing sector in Nigeria from 1980 to 2015. The econometrics methods of ordinary least squares, co-integration, error correction model and granger causality test were used as the main analytical tools. From the estimated error correction model, the study out found that bank credits to the manufacturing sector had a positive impact on the manufacturing sector output. In addition, the granger causality result reveals that there is causal relationship between bank credits and manufacturing sector output in Nigeria.

\subsection{Methods and Materials}

This study is designed to access the effects of bank credits on the manufacturing sector output in Nigeria from 1981 to 2018. To achieve this, an ex-post-facto research design was employed because the events that are observed in this study had taken place and nothing can be done to change the figures, but can only be observed in order to analyze it. A multiple regression analysis would be used to measure the relationship between these variables. The data used for the purpose of this study are from secondary sources. There data were sourced mainly from the Central Bank of Nigeria Statistical Bulletin, 2018 series.

This study followed the ARDL Model as developed and popularized by Pesaran et al. (2001). The bound test (cointegration) and error correction method was used to model both the short run and long run relationship amongst the variables. The method has more than a few compensation over other cointegration methods for which cause it is chosen for this work. Firstly, it is well-organized in small samples and not limited in terms of stationary property of the variables under study. The move toward can allow for a mixture of $\mathrm{I}(0)$ and $\mathrm{I}(1)$ variables.

\subsection{Model Specification}

Empirically, there is a strong link between financial sector development and manufacturing performance. The link between finance and manufacturing has been empirically modelled in Levine (1997) in a study to model the relationship between financial development and economic growth in Arab countries. Similarly, Zhang, Wang and Wang (2012) also employed a similar model in tracing the link between financial development and growth in the Chinese economy. In Nigeria, the study of Mesagan, Olunkwa and Yusuf (2018) used this model also to empirically establish the relationship between financial development and manufacturing sector development in Nigeria. To this end, this present study follows Levine (1997) and Zhang, Wang and Wang (2012) and Mesagan, Olunkwa and Yusuf (2018) in specifying a functional relationship for financial sector and manufacturing sector output in Nigeria.

In testing the validity of the already stated objectives, this model used; manufacturing sector output is a function of deposit money banks credits, broad money supply, inflation rate and interest rate. Mathematically this can be expressed as:

MSO = $\mathrm{f}(\mathrm{CMS}$, BMS INF,INT).

The above functional relationship of the model can be transformed to econometric form as presented below:

$\log \mathrm{MSO}=\alpha_{0}+\alpha_{1} \log \mathrm{CMS}+\alpha_{2} \operatorname{LogBMS}+\alpha_{3} \operatorname{LogINT}+\alpha_{4} \operatorname{LogINF}+\mu$

Where,

MOS = Manufacturing Sector Output

CMS = Credit to Manufacturing Sector

$\mathrm{FSD}=$ Financial Deepening

INT $=$ Bank Interest Rate

$\mathrm{INF}=$ Inflation Rate

$\alpha 0=$ Constant

$\alpha_{1-} \alpha_{4=}$ parameters to be estimated

$\mu=$ Error term.

LOG= Logarithm 
4.0 Data analysis and interpretations

Table 1: Test of stationarity

\begin{tabular}{|l|l|l|l|l|}
\hline Series & ADF Test Statistic & $\mathbf{5 \%}$ Critical Value & Order & Remarks \\
\hline MOS & 4.582117 & 2.945842 & $1(1)$ & Stationary \\
\hline CMS & 4.577390 & 2.948404 & $1(1)$ & Stationary \\
\hline FSD & 3.663891 & 2945842 & $1(1)$ & Stationary \\
\hline ITR & 6.136412 & 2.945842 & $1(1)$ & Stationary \\
\hline IFR & 3.363144 & 2.943427 & $1(0)$ & Stationary \\
\hline
\end{tabular}

\section{Source: Compilation from E-views output}

The Unit root test results in Table 1 above shows that the variables are integrated of different orders which justifies the use of the ARDL. While IFR is integrated at level, variables like MOS, CMS, FSD and ITR are all integrated atorder one or first difference this combination essentially validates the choice of ARDL.

\section{Table 2:Cointegration Test}

ARDL Bounds Test

Included observations: 37

Null Hypothesis: No long-run relationships exist

\begin{tabular}{lcc}
\hline \hline Test Statistic & Value & $\mathrm{k}$ \\
\hline \hline F-statistic & 7.879746 & 4 \\
\hline \hline Critical Value Bounds & & \\
\hline \hline Significance & I0 Bound & I1 Bound \\
\hline \hline $10 \%$ & 2.45 & 3.52 \\
$5 \%$ & 2.86 & 4.01 \\
$2.5 \%$ & 3.25 & 4.49 \\
$1 \%$ & 3.74 & 5.06 \\
\hline \hline
\end{tabular}

The bound test is an F-test of joint significance of the lagged variables. In this context, we conclude in favor of addition among the variables in spite of of whether they are stationary. The ARDL model estimation on Table 2 allows for the bounds co-integration tests. The bounds test result on table above showed that the fstatistic value of 7.879746 is greater than the Critical Value Bounds for the upper bound I(1) at 5\% level of significance, thus, there is co-integration as such there is long-run relationship.

Table 3: ARDL Cointegrating and Long Run Form

\begin{tabular}{|c|c|c|c|c|}
\hline \multicolumn{5}{|c|}{ Cointegrating Form } \\
\hline Variable & Coefficient & Std. Error & t-Statistic & Prob. \\
\hline D(ITR) & 0.206825 & 0.095416 & 2.167610 & 0.0380 \\
\hline D(IFR) & 0.007305 & 0.032936 & 0.221795 & 0.8259 \\
\hline $\mathrm{D}(\mathrm{FSD})$ & 0.159442 & 0.089632 & 1.778851 & 0.0851 \\
\hline D(CMS) & 0.007721 & 0.115491 & 0.066850 & 0.9471 \\
\hline CointEq(-1) & -0.231928 & 0.122023 & -1.900697 & 0.0667 \\
\hline $\begin{array}{c}\text { Cointeq }=\text { MSO }-(0 \\
-0.4916)\end{array}$ & $+0.0315 * \mathrm{IF}$ & $6875 * \mathrm{FSD}$ & $333 * \mathrm{CMS}$ & \\
\hline
\end{tabular}


The result in table 3 above shows that the coefficient of error correction mechanism (ECM) is negative 0.231928 and significant at 0.05 per cent critical level.. The significance of the ECM is an indication and a confirmation of the existence of a long run equilibrium relationship between bank credits and the manufacturing sector development in Nigeria. This collaborates with the ARDL bound test. The results confirmed that bank credits in Nigeria have an automatic mechanism which responds to deviations from equilibrium in a balancing manner. A value of (-0.231928) for the ECM coefficients suggests that a fast speed of adjustment strategy of $23 \%$. This means that approximately $23 \%$ of discrepancy the previous year is adjusted for the current year i.e. approximately $23 \%$ of disequilibria from the previous year's shock converge back to the long-run equilibrium in the current year.

\subsection{Global Statistical Results Analysis}

The econometric property of the estimated equation shows that the global utility or the overall goodness of fit is high with an F- statistics of 2618.640 and probability value of 0.0000 . From ARDL result, $\mathrm{R}^{2}$ is 0.997638 or $99.7 \%$. This implies that, at level series, about $99.7 \%$ of the total variations manufacturing sector output in Nigeria (MSO) are explained by the changes in bank credit.

The Durbin - Watson statistic from the output result is 2.040227 and it is close to 2 than O. This depicts the absence of autocorrelation. But in order to be sure of data employed, a more reliable test is conducted to check for serial correlation which is more serious than autocorrelation.

Table 4: Breusch-Godfrey Serial Correlation LM

Breusch-Godfrey Serial Correlation LM Test:

\begin{tabular}{llll}
\hline \hline F-statistic & 0.083544 & Prob. F(2,29) & 0.9201 \\
Obs*R-squared & 0.211960 & Prob. Chi-Square(2) & 0.8994 \\
\hline \hline
\end{tabular}

Breusch-Godfrey LM test statistics indicate that the model does not have significant serial correlation problem.

Table 5: ARDL short term estimates

Dependent Variable: MSO

Method: ARDL

Dynamic regressors (0 lag, automatic): ITR IFR FSD CMS

Fixed regressors: $\mathrm{C}$

\begin{tabular}{crlrr}
\hline \hline Variable & Coefficient & Std. Error & t-Statistic & Prob.* \\
\hline \hline MSO(-1) & 0.768072 & 0.122023 & 6.294489 & 0.0000 \\
ITR & 0.206825 & 0.095416 & 2.167610 & 0.0380 \\
IFR & 0.007305 & 0.032936 & 0.221795 & 0.8259 \\
FSD & 0.159442 & 0.089632 & 1.778851 & 0.0851 \\
CMS & 0.207674 & 0.095814 & 2.167486 & 0.0380 \\
C & -0.114006 & 0.297836 & -0.382780 & 0.7045 \\
\hline \hline R-squared & 0.997638 & Mean dependent var & 6.502342 \\
Adjusted R-squared & 0.997257 & S.D. dependent var & 1.958780 \\
S.E. of regression & 0.102589 & Akaike info criterion & -1.568780 \\
Sum squared resid & 0.326259 & Schwarz criterion & -1.307550 \\
Log likelihood & 35.02244 & Hannan-Quinn criter. & -1.476685 \\
F-statistic & 2618.640 & Durbin-Watson stat & 2.040227 \\
Prob(F-statistic) & 0.000000 & & \\
\hline
\end{tabular}

*Note: p-values and any subsequent tests do not account for model selection.

However, we will go on and test for individual contributions of each of these variables by looking at the objections stated at the introduction part of this study. From the table above, ITR and CMS showed 
significant relationship with manufacturing sector development in Nigeria within the period under review. Other variables; IFR, FSD manifested positive relationship but the relationship were not significant.

\subsection{Conclusion and Recommendations}

The main objective of this study is to investigate the effects of bank credit on the output of manufacturing sector output in Nigeria from 1981- 2018.It employs the bounds testing (ARDL) approach of cointegration to examine the long run and short run relationships between bank credit and manufacturing sector output in Nigeria. The bounds test suggested that the variables of interest put in the model are bound together in the long-run. The error correction term is negative and statistically significant and this shows that there exists an adjustment speed from short-run disequilibrium towards the long-run equilibrium. Given the error correction instrument outcome, the study exposed that bank credits exhibited optimistic significant impact on the presentation of manufacturing sector in Nigeria. This finding collaborates with the theoretical postulation of the Financial Intermediation Theory and the empirical works of; Ume, Obasikene, Oleka, NwadikeandOkoyeuzu(2017), Andabai and Eze, (2018), and Otubu (2019)

Based on the finding, the study therefore makes these recommendations:

1. The monetary authorities should ensure that there are available and sufficient credit allocated to the manufacturing sector in Nigeria with reasonable or affordable lending rates. This will enable the manufacturing sector in Nigeria to operate optimally.

2 For Nigeria to meet up the sustainable developmental goals as planned, efforts should be made to produce quality and affordable goods and services and government efforts should be made visible in import restrictions to control the high importation of finished goods which causes some fluctuations in the exchange rate and a decrease in demand of locally manufactured goods

3. Policies aimed at deepening the financial sector more and enhanced health status of banks should be vigorously pursued. Also the Central Bank of Nigeria should as a matter of urgency review downward the lending rate in view of this COVID-19 pandemic and its impact on businesses.

\section{References}

[1] Ade-Agoye, I. (2011), Man Ikeja holds AGM and expresses worry over poor contribution of manufacturing sector to GDP. Manufacturing Association of Nigeria News. p8.

[2] Adelegan, O.J. (2011), Infrastructure deficiencies and investment in manufacturing firms in Nigeria. Journal of Economics and International Finance, 3(9), 542-552.

[3] Adolphus, J.T., Deborah, B.P. (2014), Analysis of the role of banks in financing the agriculture and manufacturing sectors in Nigeria. International Journal of Research in Business Management (IMPACT: IJRBM), 2(2), 9-22.

[4] Andabaiand Eze (2018) Bank Credit and Manufacturing Sector Growth In Nigeria (1990-2017): A Causality Investigation. International Journal of Economics, Commerce and Management United Kingdom Vol. VI, Issue 3, March Page 326

[5] Ezirim, C.B (2007) Finance Dynamics; principles, techniques and applications, $3^{\text {rd }}$ edition.Phort Harcourt, Markowitz centre for research and development.

[6] Gbadebo A. D, Adekunle A. O and Muritala T and Fadeyi F. J (2017) Banks Credits And Manufacturing Growth In Nigeria Nigerian Journal of Management Sciences Vol. 6 No.1

[7] Levine, R. (1997). Financial Development and Economic Growth: Views and Agenda, Journal of Economic Literature, 35, $688-726$.

[8] Mesagan E, Olunkwa N and Yusuf I (2018) Financial Development and Manufacturing Performance: The Nigerian Case. Studies in Business and Economics no. 13(1)

[9] Muchingami L, Monametsi L and Paradza I (2017) Bank Lending and Manufacturing Sector Growth in Zimbabwe. International Journal of Innovative Research in Science, Engineering and Technology.Website: www.ijirset.comVol. 6, Issue 4, April

[10] Ndebbio, J.E.U. (2004), "Financial Deepening, Economic Growth and Development: Evidence from Selected sub- Saharan African Countries"African Economic Research Consortium (AERC) Research Paper 142, Nairobi, August.

[11] Nwasilike, O.T. (2006), Local Manufacturing Capacity Supporting the Energy and Power Sector in Nigeria. NCD Series.

[12] Ogar, A., Nkamere, S.E., Effiong, C. (2014), Commercial bank credit and its contributions on manufacturing sector in Nigeria. European Scientific Journal, 8(3), 19-36. 
[13] Ogunsakin, S. (2014), Nigerian financial sector and manufacturing industries.Journal of Applied Chemistry, 7(3), 41-46.

[14] Okafor, H. O.( 2016) Economic Growth, Poverty and Income Inequality Matrix in Nigeria: A Further Investigation. Central Bank of Nigeria Economic and Financial Review page 43-70

[15] Olanrewaju, O.G., Aremo, A.G., Aiyegbusi, O.O. (2015), Banking sector reforms and output growth of the manufacturing sector in Nigeria. Journal of Economics and International Finance, 7(8), 183-191

[16] Omankhanlen, O., Owonibi, A. (2012), Manufacturers and Burden of High Interest Rates. Ghanamma.com. Available from: http://www.ebcache. googleuserconten.com/search?q=cach: http://news.ghanamma. com/1/manufacturers-and-burden-of-high-interestrates/\&strip $=0$.

[17] Otubu, O. P.(2019) The Impact of Bank Credits on the Manufacturing Sector in Nigeria (1980-2015) International Journal of Science and Management Studies (IJSMS) E-ISSN: 2581-5946 Volume: 2 Issue: 4 July to August.

[18] Pesaran, M.H., Shin, Y., Smith, R.J. (2001), Bounds testing approaches to the analysis of level relationships. Journal of Applied Econometrics, 16(3), 289-326.

[19] Romer D (1990) “Does Trade Cause Growth” America Economics Review 89 pp 379-399

[20] Shaw, E. S. (1973). Financial deepening in economic development. London and New York: Oxford University Press.

[21] SogulesI.W.andNkoro E (2016) Bank Credits and Performance of Manufacturing Sector in Nigeria, 1970-2013. The Journal of Social Sciences Research Vol. 2, No. 7, pp: 129-132,

[22] Tawose, J.O.B. (2012), Bank credit and the manufacturing sector.Journal of International Business and Management, 4(2), $158-168$.

[23] Ume E.B , Obasikene A.C,Oleka C.D and Nwadike A.O Okoyeuzu C (2017) The Relative Impact of Bank Credit on Manufacturing Sector in Nigeria.International Journal of Economics and Financial Issues.Issues | Vol 7 • Issue 2

[24] World Bank (2015). Doing Business 2015: Going Beyond Inefficiency.

[25] World Bank Development Indicators (2015). Available athttp://data.worldbank.org/news/release-of-world-development-indicators2015

[26] Zhang, J., Wang, L., \& Wang, S. (2012). Financial development and economic growth: Recent evidence from China. Journal of Comparative Economics, 40(3), 393-412. 